\title{
Estimating the cost of calibration services using the TDABC costing method
}

Rodrigo Schons Arenhart ${ }^{1}$ - Universidade Federal de Santa Maria, Depto. Produção e Sistemas

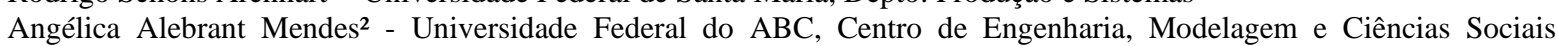
Aplicadas

Morgana Pizzolato ${ }^{3}$ - Universidade Federal de Santa Maria - Depto. Produção e Sistemas

\section{ABSTRACT}

The activity-based costing method (TDABC) emerged in the 2000 s as a simplification of the activity-based costing method $(A B C)$. Its purpose is to facilitate and reduce the costs of costing system implementation. This paper aims to estimate the cost of calibrating scales, micrometers, and calipers of a higher education laboratory through the TDABC costing method, to then evaluate the applicability of the method and to define a minimum number of calibrations to let the laboratory reach its equilibrium point. The implementation of the methodology took the following steps: i) identify activities of each service and duration times; ii) calculate the practical capacity and its costs and; iii) determine the capacity rate and multiply it by the activity times. The identification of the costs of each activity for each service analyzed, the clear verification of the method determining its applicability, the estimation of the minimum number of annual calibrations for the laboratory to reach its break-even point, and the visualization of greater financial attractiveness for the service of calibration of scales form the main results obtained.

Keywords: TDABC. Costs. Laboratory. Calibration.
Editor Responsável: Prof. Dr. Hermes Moretti Ribeiro da Silva

1. rodrigoschonsarenhart@gmail.com, Av. Roraima n. 1000, Prédio 10, sala 402, Santa Maria, RS, 97105-900; 2. angelica.mendes@ufsm.br; 3. morgana.pizzolato@gmail.com

ARENHART, R.S.; MENDES, A.A.; PIZZOLATO, M. Estimating the cost of calibration services using the TDABC costing method. GEPROS. Gestão da Produção, Operações e Sistemas, v. 15, n. 2, p. 314 - 336, 2020.

DOI: $10.15675 /$ gepros.v15i2.2535 


\section{INTRODUCTION}

Estimating product manufacturing or service costs is as important an activity as manufacturing a product or service development itself. However, what is perceived is a simplification in this type of procedure to avoid costs and make the process agile. This can provide misleading cost values, especially if the process has large manufacturing variations or different types of services offered, which can lead to considerable pricing errors.

To systematize this process, costing methods are used, among which can highlight the two methods studied in this research, the ABC (Activity-Based Costing) costing method, systematized by Kaplan and Cooper (1998), and the TDABC costing method (Time-Driven Activity-Based Costing) proposed by Kaplan and Anderson (2007). The first one has been widely used and has a large number of applications, while the second one is an adaptation of the first one, where the focus is on simplifying the steps to achieve the result.

TDABC facilitates the implementation of the costing system and uses time drivers that are calculated directly in activities related to the execution of the service or product manufacturing (KAPLAN; ANDERSON, 2007). This method presents important management information to company managers so that the decision-making process is simplified and the organization has a greater detail of its costs. According to Luna and Bornia (2017), TDABC is a simple and practical option to calculate the cost and capacity utilization of processes, as well as contribute to measuring the profitability of orders, products, and customers, creating conditions to improve the cost management system of a company.

From the studies by Kaplan and Anderson (2007), the importance of the real estimate of the costs included in the manufacturing or services provided by the companies is a determining factor for their good management and continuity. Therefore, a research question was formulated to estimate the cost of calibration activities in a laboratory of a public higher education institution in the field of mechanical metrology. The research question is: what are the costs of each calibration activity, and what is the minimum number of calibrations for the system to be balanced?

Based on this, the main objective of the research is to estimate the costs of calibration services for scales, micrometers, and calipers based on the TDABC costing method. In a second moment, do the check of the applicability of this cost estimation method in a 
laboratory, and also verify the possible implantation difficulties and improvement opportunities, and finally, to calculate the minimum number of calibrations to reach the Yearly breakeven point.

The justification of the work is technical, as it seeks to contribute to the consolidation of the methodology of the TDABC costing method, using a practical application in a service laboratory. According to Abbas et al. (2015), Brazilian research has approached the ABC and TDABC methods and suggested its implementation in companies with different purposes. Added to this is the practical opportunity to help the laboratory determine the costs of its services and contribute to its financial autonomy.

\section{LITERATURE REVIEW}

This section discusses the research theme literature. At first, an analysis is made of the main costing methods used today, and then an explanation of how the $\mathrm{ABC}$ method works. Following, the section presents the concept of the TDABC, which is an adaptation of the first method analyzed. Finally, applications of $\mathrm{ABC}$ and TDABC costing methods in service companies are presented.

\subsection{Costing methods}

Cost accounting emerged during the Industrial Revolution to determine product costs and thereby form the selling price (TOMAZI; HENRIQUE, 2016). Generally speaking, cost accounting is not difficult to calculate, since what is done, in most cases, is to subtract the costs of the products sold from the revenue obtained by selling them and from these gross profits the expenses are estimated. However, the complexity is to calculate the real cost of each product (MASCARELO et al., 2017). The practice of managing costs is intended to assist managers in their managerial functions, as it occupies a strategic role in managing the products and services of an organization through the use of the most appropriate costing system (DIAS; PADOVEZE, 2007).

In addition to ensuring good profit margins, management, control and cost reduction activities are important elements of corporate competitiveness while facing a competitive global market (GUIMARÃES et al., 2015). Costing methods are tools used by those responsible for organizations as a source of monetary and non-monetary information about 
their products and services, which support the planning, control, and execution of business strategies, as well as helping to measure their levels of inventory (HANSEN; MOWEN, 2009).

One of the challenges of managers is to apply the correct methodologies to calculate the costs of their products, considering the increased competition, more demanding customers and meeting their requirements (MASCARELO et al., 2017). Costing systems, on the other hand, have their main challenge in the insertion of indirect costs to products and services, it is usually used apportionment through criteria that managers believe are close to the reality of the organization (KREMER et al., 2012). The most prominent costing methods are absorption (and its variations), direct/variable costing, UEP (Production Effort Unit) method, ABC costing and TDABC costing (WERNKE et al., 2015).

\subsection{Activity-Based Costing (ABC)}

Activity-Based Costing (ABC) became known in the late 1990s with the work of professors Robert Kaplan and Robin Cooper (AFONSO, 2002). According to Guimarães et al. (2015), the ABC system was systematized by Kaplan and Cooper in the United States, through their experience in case studies conducted mainly at the companies Schrader Bellows and John Deere.

According to Abrantes and Marioto (2008), ABC is a methodology designed to facilitate the strategic analysis of production costs related to the activities that most impact the organization's resource consumption. The system has the basic foundation of seeking the principle of causation; In other words, identify the reason for the cost to impute value to it (CAMARGOS et al., 2017). The method gained strength due to the increase in indirect costs that occurred in companies, which served as an incentive for the elaboration of a more appropriate procedure for the allocation of this type of cost (MEGLIORINI, 2011).

According to Megliorini (2011), ABC proposes to appropriate the indirect costs to the activities, since the philosophy of the method takes into account that these activities are the cost drivers. Thus, each of the indirect costs must be related to their respective activities through resource drivers. According to Martins (2018), drivers are factors that determine the cost of activity because they need resources to be performed, and drivers are the true reason for the real cost. 
According to Kaplan and Cooper's approach (1998), the ABC costing system method can be developed through four steps: (i) developing a proper dictionary of activities; (ii) determine how much the organization is spending on each of its activities; (iii) identify products, services and customers of the organization and; (iv) select activity cost generators that associate activity costs with the organization's products, services, and customers. Luna and Bornia (2017) state that the method usually has five steps, namely: (i) identifying indirect expenses of activities; (ii) assign the indirect costs to the different activities through a resource driver; (iii) identify indirect expenses of activities; (iv) determine the activity's cost driver and; (v) multiply the driver by the consumption of the driving activity.

According to Santana et al. (2016), when using the ABC costing method, it is necessary to verify which resources are needed and used in the organization, and then to find out which are the first stage drivers, which allocate the expenses of the functional areas to the value activities that are performed in these local. Second-stage drivers allocate activity costs to costing objects, which may be products, services, or customers. Bandeira et al. (2017) explain that activities consume costs while products or services consume activities; In this way the activities start to receive costs and the cost of the product or service is defined by the amount of activities that it consumes.

To implement the ABC costing system, it is essential to have the explicit support of the administration and those responsible for the several areas involved, which should provide inputs for its implementation to discuss the method's characteristics, as well as awareness and training issues (CANHA, 2007). The main goal of the method is to solve the problem of inaccurate allocation of overhead in traditional cost systems, users report a certain complexity of the deployment, especially concerning the estimation of time dedicated to each activity (LUNA; BORNIA, 2017). The elaboration of the ABC requires a large workforce and can generate additional costs to those already existing in the company, as well as the need to conduct new interviews to keep the cost metrics updated so as not to decrease the efficiency of the method (ÁRPÁD-ZOLTÁN; KINGA- ERZSÉBET, 2016).

\subsection{Time-Driven Activity-Based Costing (TDABC)}

The high processing costs and the delay in data collection, evidenced in the application of the ABC system, generated companies dissatisfaction, which resulted in a decrease in the use of this method (RODRIGUES et al., 2014). Barros and Simões (2014) state that the ABC GEPROS. Gestão da Produção, Operações e Sistemas, v. 15, nº 2, p. 314 - 336, 2020. 
model failed to provide an effective and sustainable costing system, and that the alternative to this is the TDABC method, whose main focus is to facilitate the costing system implementation.

According to Kaplan and Anderson (2007), TDABC is a simplification of the ABC method, which requires the estimation of two variables for its use: the cost of providing resources for a given activity and the time taken to perform it. Thus, theoretically, it is considered to be a cost-effective, quick-to-deploy method that provides useful and clear information. For the deployment, identifies departments, costs, and ability to deliver to management a model of the cost and profitability of producing and delivering goods and services, and managing customer relationships.

In TDABC it is possible to compute the time effectively used in the execution of a task; This avoids attributing to the product or service the downtime of a department, which entails higher costs than those inherent in the activities performed (WERNKE et al., 2010). Mazzuco et al. (2017) profess that the method is easy to apply compared to the previous one and can be adjusted for various types of organizational environments, including being strongly applicable to companies in the service area.

Everaert et al. (2008) identify the main steps for the implementation of the methodology: (i) identify the activities performed; (ii) estimate the cost of supplied capacity; (iii) estimate the practical capacity of each activity; (iv) calculate the capacity cost rate; (v) estimate the time of each activity and; (vi) multiply the unit cost of each activity by the time required to perform it. The methodology proposed by Kaplan and Anderson (2007) divides the stages as follows: (i) preparation; (ii) analysis; (iii) pilot model and; (iv) release. In the preparation stage, the plan is developed and the project team is formed, in the second stage data are collected and time studies are carried out, where time equations and capacity cost rates are estimated. In the third stage the model is implemented and validated so that in the last phase, it is expanded to the company.

Using time equations admit describes the main activities and all variations around them, and to identify the drivers of these variations and to estimate the standard times for the main activity and each variation (DEINANI et al., 2015). However, Oliveira and Oliveira (2014) add that time estimates should be obtained as accurately as possible, especially when there are models with high unitary times. 
According to Medeiros et al. (2017), the advantage of this method over ABC is the simplification of the costing process, by eliminating the research process, to collect information regarding the allocation of costs of resources and activities before directing them to the cost object. Souza et al. (2012) mention that among the advantages of the method is the ease in modeling complex activities through time equations, and developing the model in a short time, which can generate a lower implementation cost.

Pereira and Oliveira (2016) conclude that the method offers a good number of managerial information to managers, such as the possibility of identifying the most timeconsuming activities and the most costly activities. It can also provide the discovery of the efficient cost of the organization quantifying waste of resources and facilitating the development of efficiency indicators. According to Luna and Bornia (2017), the TDABC method is a simple and practical option to determine the cost and usability of processes, and also helps to evaluate the profitability of orders, products, and customers, creating conditions for improved cost management systems.

\subsection{Application of ABC and TDABC Costing Methods}

Souza et al. (2017) used ABC costing to form the selling price in an environmental analysis laboratory; The research identified that indirect expenses corresponded to $86 \%$ of the total composition of the cost of services, besides delimiting the resources and activities that consumed higher values of the institution. The cost was not the only factor analyzed to compose the selling price of services, being attributed variables such as market price, the purchasing power of customers, and demand for the service.

Wernke et al. (2010) analyzed the superiority of the implementation of TDABC before ABC in a transport company. The superiority, advocated by Kaplan and Anderson (2007), is partially correct since summing all the monthly costs of a department or sector and dividing this value by the total capacity is a simple procedure and can be done through spreadsheets and software. Another factor is the ability to measure idle capacity, which is not possible through ABC. However, they maintain that the TDABC does not decrease the subjectivity that is imputed to the $\mathrm{ABC}$, because the same cost value is attributed to each minute of work.

Similar factors can be verified in the studies by Souza et al. (2012), in which the TDABC methodology is implemented in a retail company. The main advantages identified over the traditional method were the ease in modeling complex activities through time GEPROS. Gestão da Produção, Operações e Sistemas, v. 15, nº 2, p. 314 - 336, 2020. 
equations, short time to model development, lower implementation cost and easy integration between the model and Enterprise Resource Planning (ERP) systems. The limitations concern the degree of subjectivism identified through the interviews and the lack of standardization of some activities, interfering in the formulation of the equations of time.

Pereira and Oliveira (2016) modeled the TDABC system for costing the plastics recycling process. They consider the steps of this simpler than the steps of the $\mathrm{ABC}$ methodology, giving greater easiness of implementation, and can develop a cost system from spreadsheets reducing the financial impact of more complex systems. They state that the method presents important managerial information, such as the identification of more time consuming and costly activities, however, as reported by Wernke et al. (2010), there is a high degree of subjectivity in the method, especially in the estimation of average times.

Oliveira and Oliveira (2014) measured the cost of a research center's activities using TDABC. The key advantages of this method were that data collection was simple, reduced deployment time and cost, and easy to manage. In practice, the information obtained by applying the method help to identify tasks that consume more time and costs, enabling a managerial performance.

\section{METHODOLOGICAL PROCEDURES}

This section initially presents the object of study of the article, defining the nature, objectives, and technical procedures used in the research. Following is an explanation of the procedures for data collection and analysis. At the end of the section, the research scenario and its steps are presented.

\subsection{Study object}

The research has an applied nature since it aims to make a real application to try to solve problems identified in daily life (VENANZI; SILVA, 2016). This research has an object of study the application of the TDABC methodology in a service laboratory.

From its objectives, it has an exploratory character, aiming to provide greater familiarity with the problem to make it explicit or to make hypotheses; It generally assumes the forms of bibliographical research and case studies (MATIAS-PEREIRA, 2019). The research sought to verify the appropriateness and list advantages and disadvantages of this methodology, as well as possible adjustments to be made to improve the definition of cost GEPROS. Gestão da Produção, Operações e Sistemas, v. 15, nº 2, p. 314 - 336, 2020. 
services, providing a simplified methodology for managers to perform the task of pricing laboratory calibrations.

Concerning technical procedures, research is classified as action research because it is designed and carried out in association with an action or problem solving; researchers and participants are involved in a participatory or cooperative way (MATIAS-PEREIRA, 2019). In this case, the researchers applied the TDABC methodology together with the laboratory managers.

\subsection{Data collection procedures}

The technique of informal unstructured interviews with the manager and laboratory staff was applied to perform data collection. The unstructured interview seeks to obtain from the interviewee descriptions of a situation under study through a guided conversation. The researcher seeks to know how and why something occurs; This information can be used in qualitative analysis (MATIAS-PEREIRA, 2019). Information was raised about the organization's operation, its activities and related costs, as well as other costs, such as the acquisition of equipment and materials, labor, among others.

\subsection{Data analysis procedures}

The research approach is qualitative, with the concern of collecting information about the individual's point of view, besides interpreting the environment in which the problem is inserted (MIGUEL, 2010). The data generated by the research were compiled with the help of the electronic appliance Microsoft Excel, which aimed to assist and register the application of TDABC, as well as being a facilitator for future updates that may occur in the costs of activities. Thereby, when managers consider it necessary, the pricing of services according to the TDABC can be done.

\subsection{Research scenario and steps}

The research was conducted in a laboratory of a higher education institution. Assisted by a quality management system, which is set up in a support body, which has a set of technical-scientific laboratories that perform specialized technical service activities with the management system developed following ABNT NBR ISO/IEC 17025. The laboratory 
conducts testing and calibration activities in the areas of strength, dimensional, and mass for teaching, research, and extension.

The research steps followed the TDABC application methodology implemented by Everaert et al. (2008). Step 1: Identify the activities performed; Step 2: Estimate the cost of capacity provided by the institution on each driver; Step 3: estimate the practical capacity in minutes of each activity consumed; Step 4: Calculate the capacity cost rate; Step 5: Estimate the time for each transaction; Step 6: Multiply the unit time of each transaction by the required time per cost object. The research steps are presented in Figure 1.

Figure 1 - Research steps

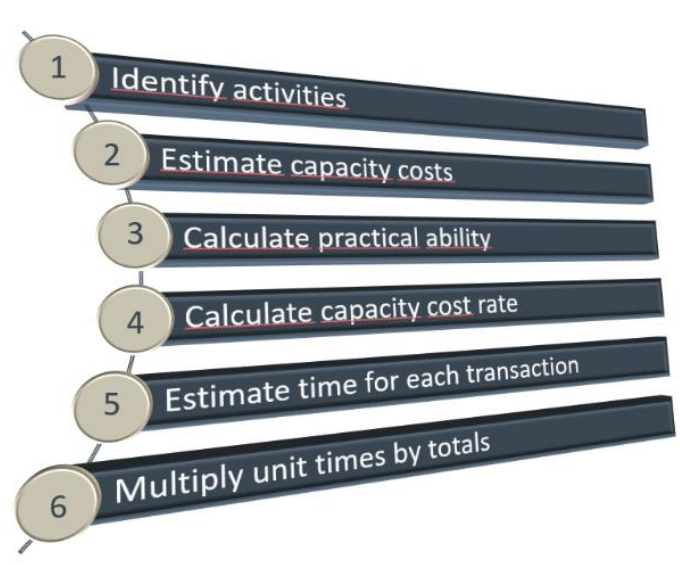

Source: Prepared by the author (2018).

In addition to the steps proposed by Everaert et al. (2008), there was the insertion of an extra step, which aims to analyze the minimum number of annual calibrations so that the laboratory does not present losses. This step was performed after the implementation of the TDABC methodology was completed based on the price of each calibration service performed by the laboratory.

\section{RESULTS AND DISCUSSION}

The research results are presented in subsections according to each step of the methodology presented in section 3.4 . 


\subsection{Identify activities}

To begin the phase that deals with the identification of activities, the object of study were divided into three services provided by the laboratory, which are in the process of accreditation by the standard ABNT NBR ISO/IEC 17025. The selected services are scale calibration, micrometer calibration and caliper calibration. To list the activities, the laboratory's internal calibration procedures were used. The activities of each service were listed in a spreadsheet and the execution time of each activity was linked according to on-site observations and unstructured interviews with laboratory staff.

The first service analyzed was the calibration of scales. The service has 14 scheduled activities, which can be reduced to 13 if the balance is already on and ready for calibration; or one action may be added if the lab staff need to move to calibrate. The activities related to the calibration of scales and the standard time of execution of each task are inserted in Table 1. Activities one to 13 are performed by metrologists, and activity 14 is assigned to the technical manager.

Table 1 - Activities related to the calibration of scales

\begin{tabular}{clc}
\hline & \multicolumn{1}{c}{ Activity } & Time (min) \\
\hline $\mathbf{1}$ & Print and Complete Data Collection Page 1 & 5 \\
\hline $\mathbf{2}$ & Do a brief survey on the balance to be calibrated & 10 \\
\hline $\mathbf{3}$ & Recommend that client make preparations & 2 \\
\hline $\mathbf{4}$ & Fill fields 1 to 3 of RC.LADIPP.09 & 2 \\
\hline $\mathbf{5}$ & If the scale is not switched on, switch on & 30 \\
\hline $\mathbf{6}$ & Check scale installation & 2 \\
\hline $\mathbf{7}$ & Handle and clean equipment and standards & 5 \\
\hline $\mathbf{8}$ & Wait for thermal stabilization & 30 \\
\hline $\mathbf{9}$ & Perform visual examination of calibration conditions & 2 \\
\hline $\mathbf{1 0}$ & Perform calibration according to RC.LADIPP.05 & 40 \\
\hline $\mathbf{1 1}$ & Fill 4 Field of RC.LADIPP.09 & 2 \\
\hline $\mathbf{1 2}$ & Handle and clean equipment and standards & 5 \\
\hline $\mathbf{1 3}$ & Prepare calibration certificate & 15 \\
\hline $\mathbf{1 4}$ & Review and sign calibration certificate & $\mathbf{1 8 0}$ \\
\hline & & Total time \\
\hline
\end{tabular}

Source: Prepared by the author (2018).

Regarding the micrometer calibration, 12 activities were identified. In this case, there was no variation in the number of activities, as they are developed in the laboratory, under 
appropriate conditions of temperature and humidity and do not have the presence of the client. The micrometer calibration activities and the standard execution time for each task are described in Table 2. Activities one through 11 are performed by metrologists and activity 12 is assigned to the technical manager.

Table 2 - Activities related to the calibration of micrometers

\begin{tabular}{llc}
\hline & \multicolumn{1}{c}{ Activity } & time (min) \\
\hline $\mathbf{1}$ & Fill data collection & 2 \\
\hline $\mathbf{2}$ & Perform micrometer visual analysis & 2 \\
\hline $\mathbf{3}$ & Clean micrometer & 5 \\
\hline $\mathbf{4}$ & Clean standards & 10 \\
\hline $\mathbf{5}$ & Thermal stabilization & 60 \\
\hline $\mathbf{6}$ & Set micrometer initial value & 5 \\
\hline $\mathbf{7}$ & Calibrate the micrometer & 20 \\
\hline $\mathbf{8}$ & Clean standards & 5 \\
\hline $\mathbf{9}$ & Clean micrometer & 5 \\
\hline $\mathbf{1 0}$ & Complete data collection fill & 2 \\
\hline $\mathbf{1 1}$ & Prepare calibration certificate & 10 \\
\hline $\mathbf{1 2}$ & Review and sign calibration certificate & 20 \\
\hline & & $\mathbf{1 4 6}$ \\
\hline
\end{tabular}

Source: Prepared by the author (2018).

The last service analyzed at this stage was caliper calibration, which also presented 12 activities. The service is performed in the laboratory only, such as micrometer calibration, under control of environmental conditions and without customer participation in the calibration service. Activities related to caliper calibration and the standard time of execution of each task are described in Table 3. Activities one to 11 are performed by metrologists and activity 12 is performed by the technical manager.

Table 3 - Activities related to the calibration of calipers

\begin{tabular}{|c|c|c|}
\hline & Activity & time (min) \\
\hline 1 & Fill data collection & 2 \\
\hline 2 & Perform caliper condition analysis & 2 \\
\hline 3 & Clean caliper & 5 \\
\hline 4 & Adjust the caliper cursor & 5 \\
\hline 5 & Clean standards & 10 \\
\hline 6 & Thermal stabilization & 60 \\
\hline 7 & Calibrate the caliper & 25 \\
\hline
\end{tabular}




\begin{tabular}{|c|c|c|}
\hline 8 & Clean standards & 5 \\
\hline 9 & Clean caliper & 5 \\
\hline 10 & Complete data collection fill & 2 \\
\hline 11 & Prepare calibration certificate & 10 \\
\hline \multirow[t]{2}{*}{12} & Review and sign calibration certificate & 20 \\
\hline & & 151 \\
\hline
\end{tabular}

Source: Prepared by the author (2018).

\subsection{Estimate capacity cost}

At this step, the resources used to perform the activities in the three services were identified. For that, unstructured interviews were used with the laboratory manager, who provided the values of equipment acquisition, calibration, maintenance, among others. The data collected are from 2014 to 2018, because over the period new equipment was acquired, as well as calibrations were performed at certain intervals, according to the standard or instrument to be calibrated.

The values presented refer to labor used in the laboratory, purchase of materials and equipment, calibration of instruments, and use of standards. The definition of costs was performed in a specific way because it allows the separation between services and inputs that are used by the activity analyzed. The hourly cost was calculated from the annual cost of the item divided by the practical capacity in hours used by the laboratory metrologists. Table 4 presents the monthly, annual, and operating hours costs (in Reais) of the laboratory, which involve the services in the study.

Table 4 - Lab operating cost

\begin{tabular}{lcccccc}
\hline \multicolumn{1}{c}{ Cost type } & Monthly cost & \multicolumn{2}{c}{ Annual cost } & \multicolumn{2}{c}{ Hour cost } \\
\hline Standard weight depreciation & $\mathrm{R} \$$ & 108.33 & $\mathrm{R} \$ 1,300.00$ & $\mathrm{R} \$$ & 1.29 \\
\hline Standard weight calibration & $\mathrm{R} \$$ & 83.33 & $\mathrm{R} \$ 1,000.00$ & $\mathrm{R} \$$ & 0.99 \\
\hline Thermohygrometer depreciation & $\mathrm{R} \$$ & 1.13 & $\mathrm{R} \$$ & 13.50 & $\mathrm{R} \$$ & 0.01 \\
\hline Thermohygrometer calibration & $\mathrm{R} \$$ & 8.33 & $\mathrm{R} \$$ & 100.00 & $\mathrm{R} \$$ & 0.10 \\
\hline Barometer depreciation & $\mathrm{R} \$$ & 2.50 & $\mathrm{R} \$$ & 30.00 & $\mathrm{R} \$$ & 0.03 \\
\hline Barometer calibration & $\mathrm{R} \$$ & 12.50 & $\mathrm{R} \$$ & 150.00 & $\mathrm{R} \$$ & 0.15 \\
\hline Standard level depreciation & $\mathrm{R} \$$ & 3.33 & $\mathrm{R} \$$ & 40.00 & $\mathrm{R} \$$ & 0.04 \\
\hline Gloves purchase & $\mathrm{R} \$$ & 0.83 & $\mathrm{R} \$$ & 10.00 & $\mathrm{R} \$$ & 0.01 \\
\hline Brushes purchase & $\mathrm{R} \$$ & 0.17 & $\mathrm{R} \$$ & 2.00 & $\mathrm{R} \$$ & 0.00 \\
\hline Anti-corrosion oil purchase & $\mathrm{R} \$$ & 4.17 & $\mathrm{R} \$$ & 50.00 & $\mathrm{R} \$$ & 0.05 \\
\hline Isopropyl Alcohol purchase & $\mathrm{R} \$$ & 4.17 & $\mathrm{R} \$$ & 50.00 & $\mathrm{R} \$$ & 0.05 \\
\hline Ink purchase & $\mathrm{R} \$$ & 0.42 & $\mathrm{R} \$$ & 5.00 & $\mathrm{R} \$$ & 0.00 \\
\hline \multicolumn{1}{c}{ GEPROS. Gestão da Produção, Operações e Sistemas, v. 15, $\mathrm{n}^{\circ} 2, \mathrm{p} .314-336,2020}$. & &
\end{tabular}




\begin{tabular}{lcccccc} 
Micrometer support depreciation & $\mathrm{R} \$$ & 4.75 & $\mathrm{R} \$$ & 57.00 & $\mathrm{R} \$$ & 0.06 \\
\hline Standard blocks depreciation & $\mathrm{R} \$$ & 66.67 & $\mathrm{R} \$$ & 800.00 & $\mathrm{R} \$$ & 0.79 \\
\hline Standard blocks calibration & $\mathrm{R} \$$ & 52.50 & $\mathrm{R} \$$ & 630.00 & $\mathrm{R} \$$ & 0.63 \\
\hline Optical parallels depreciation & $\mathrm{R} \$$ & 33.33 & $\mathrm{R} \$$ & 400.00 & $\mathrm{R} \$$ & 0.40 \\
\hline Optical parallels calibration & $\mathrm{R} \$$ & 24.58 & $\mathrm{R} \$$ & 295.00 & $\mathrm{R} \$$ & 0.29 \\
\hline Ring gauges depreciation & $\mathrm{R} \$$ & 16.67 & $\mathrm{R} \$$ & 200.00 & $\mathrm{R} \$$ & 0.20 \\
\hline Ring gauges calibration & $\mathrm{R} \$$ & 83.33 & $\mathrm{R} \$ 1,000.00$ & $\mathrm{R} \$$ & 0.99 \\
\hline Metrologists scholarship & $\mathrm{R} \$$ & 400.00 & $\mathrm{R} \$ 4,800.00$ & $\mathrm{R} \$$ & 4.76 \\
\hline Technicians scholarship & $\mathrm{R} \$ 1,000.00$ & $\mathrm{R} \$ 12,000.00$ & $\mathrm{R} \$$ & 11.90 \\
\hline Granite table depreciation & $\mathrm{R} \$$ & 41.42 & $\mathrm{R} \$$ & 497.00 & $\mathrm{R} \$$ & 0.49 \\
\hline
\end{tabular}

Source: Prepared by the author (2018).

\subsection{Calculate practical ability}

The practical capacity was calculated based on the available time of the laboratory metrologists, since a metrologist is responsible for performing all the steps of one of the services, and in the end, the results are validated by the technical responsible. The capacity calculation was done in the same way for both positions.

Responsible technicians and metrologists receive grants to perform activities in the laboratory. Scholarships for metrologists are available for 12 months, with work being done throughout the year on a 20-hour workweek, as well as the technical manager. To define the practical capacity of each service, the annual workday of a metrologist was used, which corresponds to approximately four hours a day, for five days a week, for approximately 252 days a year, which generated 1008 hours per year for each metrologist. This same capacity is also considered for the position of technical manager.

\subsection{Calculate capacity cost rate}

TDABC has in time its main cost driver and to use this criterion is calculated the capacity cost rate of each resource group, in this case, separated into three groups - calibration of scales, micrometers, and calipers. The calculation is made by dividing the total cost of each resource group by the annual practical capacity of the same group.

As there is a differentiation in the values of scholarships received by metrologists and technicians, it was decided to separate these two factors. Costs related to equipment were incorporated with the practical capacity of the metrologist, as the responsibility for handling them is only of this group of collaborators. Table 5 presents the capacity cost rates (in Reais per minute).

GEPROS. Gestão da Produção, Operações e Sistemas, v. 15, nº 2, p. 314 - 336, 2020. 
Table 5 - Capacity cost rates

\begin{tabular}{lccccc}
\hline \multicolumn{1}{c}{ Task and task executor } & $\begin{array}{c}\text { Annual cost of } \\
\text { resources }\end{array}$ & $\begin{array}{c}\text { Annual } \\
\text { capacity } \\
\text { (min) }\end{array}$ & $\begin{array}{c}\text { Capacity cost } \\
\text { rate (\$/min) }\end{array}$ \\
\hline Scale calibration - metrologista & $\mathrm{R} \$$ & $7,445.50$ & 60480 & $\mathrm{R} \$$ & 0.12 \\
Scale calibration - technician & $\mathrm{R} \$$ & $4,000.00$ & 60480 & $\mathrm{R} \$$ & 0.07 \\
Micrometer calibration - metrologista & $\mathrm{R} \$$ & $7,709.50$ & 60480 & $\mathrm{R} \$$ & 0.13 \\
Micrometer calibration - technician & $\mathrm{R} \$$ & $4,000.00$ & 60480 & $\mathrm{R} \$$ & 0.07 \\
Caliper calibration - metrologista & $\mathrm{R} \$$ & $8,214.50$ & 60480 & $\mathrm{R} \$$ & 0.14 \\
Caliper calibration - technician & $\mathrm{R} \$$ & $4,000.00$ & 60480 & $\mathrm{R} \$$ & 0.07 \\
\hline
\end{tabular}

Source: Prepared by the author (2018).

\subsection{Estimate time for each transaction}

The times of each transaction were estimated in the first step, along with the determination of the activities performed in each service. The justification for performing this procedure in this way is due to the easiness of accompanying the activities and time measurement.

A survey of the activities performed at each service was made using standard operating procedures and interviews with those responsible for performing the services. After that, the times were timed and rounded to establish an expected operating standard. The time results of each activity for each service were presented in Tables 1, 2 and 3 for the calibration services of scales, micrometers, and calipers (respectively).

From this, it can be considered as an improvement to the present method, to reduce the number of steps, because in the first step it is possible to develop two steps present in the method, without generating rework. The result of this enhancement is a faster study development and the ease of integrating the steps while avoiding too many steps for the deployment.

\subsection{Multiply unit times by totals}

In the last step, a spreadsheet was used to determine the calculations faster and more accurately. The calibration of scales had a unit calibration cost value of $\mathrm{R} \$ 20.45$. This value considers the 14 activities defined in step 1. If there is a trip to an area outside the educational institution, the route must be analyzed and the cost of the trip should be defined. The cost of each activity and the total cost are described in Table 6. 
Table 6 - Cost of scale calibration activities

\begin{tabular}{llcc}
\hline & \multicolumn{1}{c}{ Activity } & Time (min) & Cost \\
\hline $\mathbf{1}$ & Print and Complete Data Collection Page 1 & 5 & $\mathrm{R} \$ 0.62$ \\
\hline $\mathbf{2}$ & Do a brief survey on the balance to be calibrated & 10 & $\mathrm{R} \$ 1.23$ \\
\hline $\mathbf{3}$ & Recommend that client make preparations & 2 & $\mathrm{R} \$ 0.25$ \\
\hline $\mathbf{4}$ & Fill fields 1 to 3 of RC.LADIPP.09 & 2 & $\mathrm{R} \$ 0.25$ \\
\hline $\mathbf{5}$ & If the scale is not switched on, switch on & 30 & $\mathrm{R} \$ 3.69$ \\
\hline $\mathbf{6}$ & Check scale installation & 2 & $\mathrm{R} \$ 0.25$ \\
\hline $\mathbf{7}$ & Handle and clean equipment and standards & 5 & $\mathrm{R} \$ 0.62$ \\
\hline $\mathbf{8}$ & Wait for thermal stabilization & 30 & $\mathrm{R} \$ 3.69$ \\
\hline $\mathbf{9}$ & Perform visual examination of calibration conditions & 2 & $\mathrm{R} \$ 0.25$ \\
\hline $\mathbf{1 0}$ & Perform calibration according to RC.LADIPP.05 & 40 & $\mathrm{R} \$ 4.92$ \\
\hline $\mathbf{1 1}$ & Fill 4 Field of RC.LADIPP.09 & 2 & $\mathrm{R} \$ 0.25$ \\
\hline $\mathbf{1 2}$ & Handle and clean equipment and standards & 5 & $\mathrm{R} \$ 0.62$ \\
\hline $\mathbf{1 3}$ & Prepare calibration certificate & 15 & $\mathrm{R} \$ 1.85$ \\
\hline $\mathbf{1 4}$ & Review and sign calibration certificate & 30 & $\mathrm{R} \$ 1.98$ \\
\hline & & Total cost & $\mathbf{R} \mathbf{2 0 . 4 5}$ \\
\hline
\end{tabular}

Source: Prepared by the author (2018).

The unit cost of micrometer calibration was based on the 12 activities provided for in step 1 and totaled R\$ 17.38 per calibrated unit. A smaller value compared to scales, although there is a time difference for thermal stabilization, 30 minutes for scales versus at least one hour for micrometers and instruments used for their calibration. The scale calibration activity presents a larger number and its capacity rate is practically identical to the micrometer calibration capacity rate. The costs of micrometer calibration activities are shown in Table 7.

Table 7 - Cost of micrometer calibration activities

\begin{tabular}{|c|c|c|c|}
\hline & Activity & Time (min) & Cost \\
\hline 1 & Fill data collection & 2 & $\mathrm{R} \$ 0.25$ \\
\hline 2 & Perform micrometer visual analysis & 2 & $\mathrm{R} \$ 0.25$ \\
\hline 3 & Clean micrometer & 5 & $\mathrm{R} \$ 0.64$ \\
\hline 4 & Clean standards & 10 & $\mathrm{R} \$ 1.27$ \\
\hline 5 & Thermal stabilization & 60 & $\mathrm{R} \$ 7.65$ \\
\hline 6 & Set micrometer initial value & 5 & $\mathrm{R} \$ 0.64$ \\
\hline 7 & Calibrate the micrometer & 20 & $\mathrm{R} \$ 2.55$ \\
\hline 8 & Clean standards & 5 & $\mathrm{R} \$ 0.64$ \\
\hline 9 & Clean micrometer & 5 & $\mathrm{R} \$ 0.64$ \\
\hline & Complete data collection fill & 2 & $\mathrm{R} \$ 0.25$ \\
\hline
\end{tabular}

GEPROS. Gestão da Produção, Operações e Sistemas, v. 15, nº 2, p. 314 - 336, 2020. 


\begin{tabular}{llcc}
\hline 11 & Prepare calibration certificate & 10 & $\mathrm{R} \$ 1.27$ \\
\hline $\mathbf{1 2}$ & Review and sign calibration certificate & 20 & $\mathrm{R} \$ 1.32$ \\
\hline & & Total cost & $\mathbf{R} \$ \mathbf{1 7 . 3 8}$ \\
\hline
\end{tabular}

Source: Prepared by the author (2018).

The last activity evaluated was caliper calibration and, as well as micrometer calibration, presented a lower price compared to the calibration of scales, totaling $\mathrm{R} \$ 19.12$. The reason for the lower cost about scale calibration is that it has a shorter operating time, and the difference in costs between caliper and micrometer calibrations is a long time spent in caliper calibration and a higher capacity cost. The costs of caliper calibration activities are described in Table 8 .

Table 8 - Cost of caliper calibration activities

\begin{tabular}{clcc}
\hline & \multicolumn{1}{c}{ Activity } & Time (min) & Cost \\
\hline $\mathbf{1}$ & Fill data collection & 2 & $\mathrm{R} \$ 0.27$ \\
\hline $\mathbf{2}$ & Perform caliper condition analysis & 2 & $\mathrm{R} \$ 0.27$ \\
\hline $\mathbf{3}$ & Clean caliper & 5 & $\mathrm{R} \$ 0.68$ \\
\hline $\mathbf{4}$ & Adjust the caliper cursor & 5 & $\mathrm{R} \$ 0.68$ \\
\hline $\mathbf{5}$ & Clean standards & 10 & $\mathrm{R} \$ 1.36$ \\
\hline $\mathbf{6}$ & Thermal stabilization & 60 & $\mathrm{R} \$ 8.15$ \\
\hline $\mathbf{7}$ & Calibrate the caliper & 25 & $\mathrm{R} \$ 3.40$ \\
\hline $\mathbf{8}$ & Clean standards & 5 & $\mathrm{R} \$ 0.68$ \\
\hline $\mathbf{9}$ & Clean caliper & 5 & $\mathrm{R} \$ 0.68$ \\
\hline $\mathbf{1 0}$ & Complete data collection fill & 2 & $\mathrm{R} \$ 0.27$ \\
\hline $\mathbf{1 1}$ & Prepare calibration certificate & 10 & $\mathrm{R} \$ 1.36$ \\
\hline $\mathbf{1 2}$ & Review and sign calibration certificate & 20 & $\mathrm{R} \$ 1.32$ \\
\hline & & Total cost & $\mathbf{R} \mathbf{1 9 . 1 2}$ \\
\hline
\end{tabular}

Source: Prepared by the author (2018).

In addition to the total cost of each calibration, the cost of the foundation that issues the invoices for each service must be calculated. The agency is linked to the institution and works with a percentage of $18 \%$ on the invoice issued. This amount is intended to offset the operating costs of the laboratory itself and the institution. The value is calculated from the sale value of the service, and Table 9 shows the total costs of increasing the invoice value on each of the services analyzed. 
Table 9 - Total costs with invoice value increment

\begin{tabular}{lccc}
\hline & Scales & Micrometers & Calipers \\
\hline Price of service & $\mathrm{R} \$ 200.00$ & $\mathrm{R} \$ 30.00$ & $\mathrm{R} \$ 35.00$ \\
$\%$ invoice & $\mathrm{R} \$ 36.00$ & $\mathrm{R} \$ 5.40$ & $\mathrm{R} \$ 6.30$ \\
Unit cost & $\mathrm{R} \$ 20.45$ & $\mathrm{R} \$ 17.38$ & $\mathrm{R} \$ 19.12$ \\
Total unit cost & $\mathrm{R} \$ 56.45$ & $\mathrm{R} \$ 22.78$ & $\mathrm{R} \$ 25.42$ \\
\hline
\end{tabular}

Source: Prepared by the author (2018).

\subsection{Estimative of the minimum number of calibrations}

This step was performed from the sum of the annual fixed costs for the calibration of scales, micrometers, and calipers. Annual fixed costs were estimated based on equipment and standards depreciation and standards calibration costs used in each of the calibration services, as well as labor costs that perform direct calibration procedures.

The price of each calibration service was set as currently practiced by the laboratory. The minimum calibration number of each equipment was calculated by dividing the annual fixed costs by the price of each calibration service, less the variable cost per invoice issue. The minimum number of calibrations is in Table 10. The annual costs of each service vary from one another as the equipment used is different and has different maintenance costs, for example, the standard weight depreciation and calibration which is only linked to scale calibration. In some cases the fixed cost may be assigned to two or more services, so the cost value is divided by the number of services in which it is allocated, for example, standard block depreciation and calibration which can be used in micrometer and caliper calibrations.

Table 10 - Minimum calibration number

\begin{tabular}{|c|c|c|c|}
\hline & Scales & Micrometers & Calipers \\
\hline Annual cost & $\mathrm{R} \$ 7,361.83$ & $\mathrm{R} \$ 6,581.33$ & $\mathrm{R} \$ 6,486.33$ \\
\hline Service price & $\mathrm{R} \$ 200.00$ & 30.00 & 35.00 \\
\hline Variable cost & 36.00 & 5.40 & 6.30 \\
\hline Minimum number & 45 & 268 & 227 \\
\hline
\end{tabular}

Source: Prepared by the author (2018).

The results generated by the research are presented since the cost estimate is in the reality of the laboratory, and the market. When comparing with previous studies, it is seen that the TDABC method presents results in a short time, easily compared to the $\mathrm{ABC}$, helping in the management control process of the laboratory. However, there is a high degree of 
subjectivity in the methodology, mainly to estimate the costs of each activity, corroborating the results obtained by Wernke et al. (2010), Souza et al. (2012), Oliveira and Oliveira (2014), Pereira and Oliveira (2016) and Souza et al. (2017).

A high total cost of service for the laboratory was noticed in micrometer and caliper calibrations, mainly due to the perspective of acquiring the market from a competitive price. On the other hand, the total cost of the scale calibration service is low compared to the market-based estimated price, which allows the laboratory to prioritize this type of service to maintain its activities.

The study states that the TDABC costing method is a simple and effective tool for time-based cost allocation by activities. From the application of the steps, it was possible to visualize the main activities developed and the related cost components according to the time spent in each one. Regarding the structuring of the method, it may be suggested to anticipate and incorporate the fifth step (Estimate time of each transaction) in the first step (Identify activities), generating a new step 1 (Identify and estimate the time of activities).

\section{CONCLUSIONS}

The main objective of the research was to estimate the cost of calibration services for scales, micrometers, and calipers; achieved after the implementation of the TDABC costing methodology. At first, a bibliographic review was performed to evaluate and select the costing method that best operative the laboratory characteristic, choosing the TDABC method, as it is a simpler and more direct version of the ABC costing method.

In a second moment, there was the determination of the methodology that would be employed in the implementation of the study - Everaert et al. (2008) - to begin collecting data and determining results. As for the results, in the first phase of the project, two steps of the method of Everaert et al. (2008) were grouped to identify the activities involved in the process and to quantify the time of each activity in the same time interval. From this grouping, the method can be reduced in one step, totaling five steps, to facilitate and accelerate its implementation.

Estimating costs were simple and direct, as the laboratory has well-determined costs and the support of the university. There was greater difficulty in determining the timing of each activity and practical ability. In the first case, because it is a follow-up in a short period, 
it may not have the same value over time and in the second because it considers an entire year of work, when in some moments this sum may not reach as many hours, although it is the ideal scenario for laboratory operation.

The unit fixed costs of each service were determined based on the summed times of each activity multiplied by the capacity rate of that activity. From the determination of unitary fixed costs, the variable costs were verified, starting from the price charged for each calibration, because of the invoice dispatching body stores $18 \%$ of the value of each service. With the fixed and variable cost information, as well as the selling price of each calibration, the minimum number of calibrations to reach the break-even point for each service was calculated.

The result of costs incurred was considered within the reality of the laboratory and the market. This is due to observations made based on the calibration market and the laboratory's cost structure. When analyzing the services individually, it is clear that the calibration of scales has a low cost and a high added value of service commercialization, different from the micrometer and caliper calibrations. Thereby the laboratory can prioritize this type of service to achieve its financial balance with greater agility since the scales calibration break-even point is 45, while for micrometers and calipers these numbers rise to 268 and 227 , respectively.

The results generated by the enforcement of the TDABC costing method allow visualizing a simple and agile application, besides presenting a standardized management control through the updating and improvement of spreadsheets. In the scientific field, there is the contribution of research to consolidate the use of this methodology in the estimation of operating costs in organizations. In practical aspects, the work helps in structuring the costs of services provided by the laboratory and aid greater management control.

As a suggestion for future work is the application of the TDABC costing method in other services of the laboratory that are not in the process of accreditation by the ABNT NBR ISO/IEC 17025 standard, such as force tests using the universal testing machine, and dimensional testing, using coordinate measuring machine. Although they are not accredited by the standard in these services, there is the technical capacity to perform them, and thus, there may be a contribution to distributing the laboratory's fixed costs, especially those related to the calibration and depreciation of instruments and standards. 


\section{References}

ABBAS, K.; GREJO, L. M.; PAVÃO, J. A.; VELOSO, C. N.; CAMACHO, R. ABC e TDABC em organizações hospitalares: uma análise descritiva da literatura nacional e internacional. In: CONGRESSO INTERNACIONAL DE COSTOS, 14., 2015, Medellín. Anais... Medellín: Intercostos, 2015.

ABRANTES, F. M. G.; MARIOTO, S. L. Método de custeio baseado na atividade - ABC. Revista de Ciências Gerenciais, v. 12, n. 16, p. 105-120, 2008.

AFONSO, P. S. L. P. Sistemas de custeio no âmbito da contabilidade de custos: o custeio baseado nas actividades, um modelo e uma metodologia de implementação. 2002. $274 \mathrm{f}$. Dissertação (Mestrado em Engenharia Industrial) - Universidade do Minho, Braga, 2002.

ÁRPÁD-ZOLTÁN, F.; KINGA-ERZSÉBET, B. Aplication of ABC method from an operator of water and sewerage. Academica Brâncusi Publisher, v. 1, p. 234-239, 2016.

BANDEIRA, G. G.; BENIN, M. M.; DE SOUZA, M. A.; MACHADO, D. G. Utilização de métodos de custeio para fins gerenciais: aderência empírica em empresas da região sul do Brasil. SINERGIA. Revista do Instituto de Ciências Econômicas, Administrativas e Contábeis (ICEAC), v. 21, n. 1, p. 67-78, 2017.

BARROS, R. S.; SIMÕES, A. M. D. Do custeio tradicional ao time-driven activity-based costing: revisão de literatura e sugestões de investigação futura. RIGC, v. 12, n. 24, 2014.

CAMARGOS, M. G.; COSTA, M. L. Z.; MIRANDA, E. S. Custos variáveis de produção de Diachasmimorpha Longicaudata (Ashmead) para controle de moscas-das-frutas. Revista iPecege, v. 3, n. 2, p. 9-25, 2017.

CANHA, M. H. O método ABC como fator de competitividade da empresa. Revista TOC, $\mathrm{n}$. 84, p. $52-58,2007$.

DEINANI, R.; SANTOS, S. R.; KALNIN, J. L. Aplicação do método TDABC - time-driven activity-based costing em uma propriedade da agricultura familiar. In: CONGRESSO BRASILEIRO DE CUSTOS, 22., 2015, Foz do Iguaçu. Anais... Foz do Iguaçu: ABC, 2015.

DIAS, E. A.; PADOVEZE, C. L. Os diferentes métodos de custeio e sua implicação na apuração de custo do produto: um estudo de caso em empresa de graxas e óleos industriais. Revista Eletrônica Gestão e Sociedade, v.1, n. 2, 2007.

EVERAERT, P.; BRUGGEMAN, W.; SARENS, G.; ANDERSON, S.; LEVANT, Y. Cost Modeling in logistics using time-driven abc. Experiences from a wholesaler. International Journal of Physical Distribution \& Logistics Management, v. 38, n. 3, p. 172-191, 2008.

GUIMARÃES, L. S.; MEDEIROS, H. S.; SANTANA, A. F. B.; PEREIRA, M. S. Redução de custos no processo produtivo com a utilização do ABC e Ferramentas Lean: estudo de caso em uma indústria de componentes de refrigeração. GEPROS. Gestão da Produção Operações e Sistemas, v. 10, n. 1, p. 157-175, 2015.

HANSEN, D. R.; MOWEN, M.M. Gestão de custos: contabilidade e controle. São Paulo: Cengage Learning, 2009.

KAPLAN, R. S.; ANDERSON, S. R. Time-Driven Activity-Based Costing: A simpler and more powerful path to higher profits. Boston: Harvard Business School Plublishing Corporation, 2007. 
KAPLAN, R. S.; COOPER, R. Custo e desempenho: administre seus custos para ser mais competitivo. São Paulo: Futura, 1998.

KREMER, A. W.; BORGERT, A.; RICHARTZ, F. Desenvolvimento de um modelo de custeio híbrido para empresas prestadoras de serviço por encomenda. Revista Catarinense da Ciência Contábil, v.11, n.31, p. 57-71, 2012.

LUNA, M. B.; BORNIA, A. C. Custeio baseado em atividade e tempo: um estudo comparativo com o custeio baseado em atividades. GEPROS. Gestão da Produção Operações e Sistemas, v. 12, n. 2, p. 220-238, 2017.

MARTINS, E. Contabilidade de custos. 11. ed. São Paulo: Atlas, 2018.

MASCARELO, K.; PFÜLLER, E. E.; FEDERIZZI, R.B. Gestão de custos: o método ABC em uma indústria de fibras. Revista GESTO, v. 5, n. 2, p. 84-100, 2017.

MATIAS-PEREIRA, J. Manual de metodologia da pesquisa científica. 4. ed. São Paulo: Atlas, 2019.

MAZZUCO, M. A. S.; WRONSKI, P. G.; ZONATTO, V. C. S. Custeio Baseado em Atividades e Tempo (TDABC): um estudo em uma instituição de ensino superior do sul do estado de Santa Catarina. In: CONGRESSO BRASILEIRO DE CUSTOS, 24., 2017, Florianópolis. Anais... Florianópolis: ABC, 2017.

MEDEIROS, H. S.; SANTANA, A. F. B.; GUIMARÃES, L. S. O uso dos métodos de custeio nas indústrias de manufatura enxuta: uma análise da literatura. Gestão e Produção, v. 24, n. 2, p. 395-406, 2017.

MEGLIORINI, E. Custos. 3. ed. São Paulo: Pearson, 2011.

MIGUEL, P. A. C. Metodologia de pesquisa em engenharia de produção e gestão de operações. Rio de Janeiro: Elsevier, 2010.

OLIVEIRA, J. R.; OLIVEIRA, S. B. Mensuração do custo das atividades de um centro de pesquisas utilizando o TDABC. In: CONGRESSO BRASILEIRO DE CUSTOS, 21., 2014, Natal. Anais... Natal: ABC, 2014.

PEREIRA, F. I.; OLIVEIRA, F. T. Modelagem do Custeio Baseado em Atividade e Tempo (TDABC) em uma empresa prestadora de serviços de reciclagem de plásticos. In: CONGRESSO BRASILEIRO DE CUSTOS, 23., 2016, Porto de Galinhas. Anais... Porto de Galinhas: ABC, 2016.

RODRIGUES, E. Z.; SILVA, W. A. C.; ARAÚJO, E. A. T. Custeio baseado em atividade e tempo - tdabc: estudo de caso em uma instituição de ensino superior particular. In: CONGRESSO USP: CONTROLADORIA E CONTABILIDADE, 14., 2014, São Paulo. Anais... São Paulo: Fipecafi, 2014.

SANTANA, A. F. B.; MEDEIROS, H. S.; GUIMARÃES, L. S.; FAGUNDES, J. A.; FUNCHAL, J. A. Equações de custos para modelação de custos: aplicação do ABC Matricial. GEPROS. Gestão da Produção, Operações e Sistemas, v. 11, n. 1, p. 197-215, 2016.

SOUZA, A. A.; AVELAR, E. A.; BOINA, T. M.; CAIRES, N. A. Aplicação do time-driven ABC em uma empresa varejista. ABCustos, v. 7, n. 2, p. 26-52, 2012.

SOUZA, R. R.; CASTANHA, E. T.; MONTEIRO, J. J.; MILANESE, C. C.; CITTADIN, A. $\mathrm{O}$ uso do custeio $\mathrm{ABC}$ para formação do preço de venda em um laboratório de análises GEPROS. Gestão da Produção, Operações e Sistemas, v. 15, nº 2, p. 314 - 336, 2020. 
ambientais. In: CONGRESSO BRASILEIRO DE CUSTOS, 24., 2017, Florianópolis. Anais... Florianópolis: ABC, 2017.

TOMAZI, L. F.; HENRIQUE, D. C. Aplicação do método de custeio por absorção integral por centro de custos em uma empresa multiplanta de cerâmica vermelha estrutural com diferentes graus de automatização. Iberoamerican Journal of Industrial Engineering, v. 8, n. 16, p. 120-146, 2016.

VENANZI, D.; SILVA, O. R. Introdução à Engenharia de Produção: conceitos e casos práticos. Rio de Janeiro: LTC, 2016.

WERNKE, R.; MENDES, E. Z.; LEMBECK, M. ABC versus TDABC: estudo de caso em transportadora. In: CONGRESSO BRASILEIRO DE CUSTOS, 17., 2010, Belo Horizonte. Anais... Belo Horizonte: ABC, 2010.

WERNKE, R.; JUNGES, I.; LEMBECK, M.; ZANIN, A. Determinação do custo fabril pelo método UEP: estudo de caso no setor de salsicharia de frigorífico. GEPROS. Gestão da Produção, Operações e Sistemas, v. 10, n. 1, p. 139-156, 2015. 